\title{
Security Measures in Russia and Germany: Comparative Legal Analysis
}

\author{
T. F. Miniazeva \\ Doctor of Law, Professor of Chair of Criminal Law and Procedure, Law Department of Peoples' Friendship University of Russia \\ E-mail: minyazeva2008@rambler.ru
}

\begin{abstract}
A.V. Serebrennikova
Doctor of Law, Professor of Chair of Criminal Law and Procedure, Law Department of Lomonosov Moscow State University E-mail: serebranna@hotmail.com
\end{abstract}

\section{Doi:10.5901/mjss.2015.v6n2s4p141}

\begin{abstract}
The article deals with other measures of criminal legal nature in Russia and Germany. The basis and criteria for their use are identified. The authors set out the similarities and differences of such measures and their distinction from punishment.
\end{abstract}

Keywords: crime; punishment; security measures; other measures of criminal legal nature; the purpose of security measures; socially dangerous persons.

All the measures applied to persons, committed wrongful acts may be deemed to be security measures. The legislation of many states attaches this term criminal legal value which distinguishes them from punishment. Other than punishment security measures are referred to in many ways across the world, e.g. "correctional and security measures" in Germany (§ 61-70 of Criminal Code (hereinafter referred to as CC) of Germany), "security measures" - in Italy, Spain and Somalia (arts. 202-208 of CC of Italy; arts. 95-105 of CC of Spain; arts. 162-180 of CC of Somalia), "other measures of criminal legal nature" - in Russia (arts. 90, 91, 97, 99, 1041,1042,1043 of CC of the RF); "prevention measures" - in Austria (arts. 21-25 of CC of Austria) etc. (Dodonov V.N., 2009).

A summary of analysis of rules on security measures throughout the world allows us to define them as a set of preventive measures established by criminal law and applied by competent authorities to the person, found to be socially dangerous due to his mental state or psychotropic substances consumption, minority, non-attainment of the age for criminal liability and expressed in restriction of his rights and freedoms up to isolation from society to prevent this person from committing socially dangerous acts and (or) for the purpose of curing him or improving mental state. These are independent forms of criminal law enforcement. They shall be ordered to a person found to be dangerous for the society, be implemented either in the framework of criminal liability or with the exemption from it, be governed by the norms of General Part of Criminal Code; be applied on behalf of the state for committing acts as provided for in the norms of Special Part of Criminal Code.

The term "other measures of criminal legal nature" appeared in CC of the RF from the date of its enactment, however, separation of their various forms in special Section VI (Chapters 15 и 151) occurred ten years after, in 2006. It should be pointed out that Section VI of the CC contains only compulsory measures of a medical nature (Chapter 15) and the forfeiture of property (Chapter 151), while compulsory educational measures are contained in Section $\mathrm{V}$ of the CC of the RF (art. 87, p. 2; arts. 90, 91). The minors committed crime of small or medium gravity may be subjected to these measures as a special form of their exemption from criminal responsibility. At the same time, art. 90, p. 4 of the CC of the RF contains a provision that if the minor systematically fails to abide by compulsory educational measure such measure shall be revoked on the proposal of the competent authority and proceedings are initiated for bringing the minor to criminal responsibility.

Correctional and security measures are the specific criminal legal institute of CC of Germany. Their special feature is that they are legal consequence not only when the guilt of the person is established by the court and the court handed down a sentence, but a number of them can be assigned in certain cases specified by law in the absence of a person's guilt, for example, when placing in mental hospital. The basis for the application of these measures pursuant to $\S 62$ of the PC of Germany is the action, committed by the subject and the level of danger posed by it. Professor N. F. Kuznetsova noted that the main criterion for application of security measures is "the danger of the subject determined by 
the danger of his way of life and way of thinking". She noted that "the elimination, suppression of this danger is the main goal of correctional and security measures" (Kuznuetsova N.V., Veltsel L., 1980).

As preventive measures correctional and security measures have been introduced into the system of the legal consequences of the acts prescribed in the CC by the so-called Habitual Criminals Act of 11.24.1933.

In general, when applying correctional and security measures, according to the German legal scholars, the purpose of re-socialization and preventive functions have been the most fully addressed.

Among German and Russian legal scholars studying German criminal law, there is ambiguous attitude towards the correctional and security measures. For instance, Professor K. Lackner considers that "the Criminal Code is based on double-track (dualistic) system. The measures along with the punishment form in it the second main type of legal consequences. While the punishment is limited by the principle of guilt and pursues preventive objectives only to a limited extent, the measures serve to the protection of society from dangerous criminal..."

One of the differences between correctional and security measures and punishment is that they pursue different aims. Professor K. Lackner emphasizes that "at present time there are ongoing extensive debates on transformation, limitation or complete elimination of system of measures at all". Professor N. F. Kuznetsova has also noted that a number of German legal scientists spoke "of "double-track system" crisis for a variety of reasons. Firstly, security measures are not based on guilt. The principle of finding person to be dangerous without his guilt is extremely controversial and uncertain. Secondly, the legal nature of many security measures is unclear and therefore they can not always be distinguished from punishment. Thirdly, many of them are more repressive than punishment." These statements in general can be agreed with. However, it is noteworthy that German legislator does not qualify correctional and security measures as punishment and distinguishes them from additional penalties and additional effects. Although the rules on correctional and security measures are contained in third section "Legal Consequences of the Act" of the General Part of German Criminal Code, they do not mingle with any kind of above mentioned legal consequences of the acts and represent an independent group of rules incorporated in the sixth chapter "Correctional and Security Measures". This chapter contains the legal prescriptions determining not only the system of these measures, but also the specifics of institution of legal consequences of the act, for example, the sequence of their execution, the replacement of one measure with other measure in execution process, the conditional suspension of correctional and security measures and a number of other points. This emphasizes their specificity as such legal prescriptions for penalties are included in other chapters of the section specified, for example, in the second chapter "Assignment of Punishment", in the fourth chapter "Conditional Deferral of Punishment". Thus, German legislator even terminologically distinguishes correctional and security measures, although, certainly, the difference in legal nature of penalties and some correctional and security measures is sometimes difficult to see. Some inconsistency of German legislator, in our opinion, is revealed if we consider the General Part of the CC of Germany from a systemic point of view. The rules on correctional and security measures, as has already been noted, are set in the section "Legal Consequences of the Act", although in some cases the person has not been convicted yet, and there is only a probability of conviction in the case of "expected act" (§ 62), which reflects a preventive function of such measures. Therefore, in general we can not say that correctional and security measures may be appointed without guilt.

Correctional and security measures may be distinguished from punishment by their terms and types.

The list of correctional and security measures is defined in $\S 61$ of the CC of Germany and is exhaustive. They are:

1) mental hospital orders;

2) custodial addiction treatment orders;

3) detention for the purpose of prevention;

4) supervision orders;

5) disqualification from driving;

6) disqualification from exercising a profession.

The underlying principle for assignment of all these correctional and security measures is principle of proportionality set in $\S 62$ of the Criminal Code of Germany. It lies in proportionality of assigned correctional and security measure "to the act committed by or expected to be committed by the convicted person and to the degree of danger he poses to society".

Correctional and security measures may be classified into two groups: 1) custodial measures (including first three correctional and security measures of outlined above), and 2) other, e.g. non-custodial measures (including last three correctional and security measures of outlined above).

As an example of custodial measures, it is worth to briefly describe mental hospital orders and custodial addiction treatment orders.

Thus, mental hospital order (§ 63) is possible subject to a set of conditions: 
a) commission of unlawful act (crime or offence) in a state of insanity (§ 20) or diminished responsibility (§ 21);

b) if comprehensive evaluation of the person and his act leads to the conclusion that as a result of his condition, future serious unlawful acts can be expected of him and that he therefore presents a danger to the general public. Thus, the possibility of future commission of unlawful acts by person shall exist. It should be noted that in case of mental hospital order (§ 20) this measure is assigned without regarding the guiltiness of person, since he acts no mens rea though carries out an act provided for in CC which is typical for German criminal legal conception. If person acts in a state of diminished responsibility (\$21), the punishment may be mitigated and together with the punishment the measure concerned is ordered.

In its turn, custodial addiction treatment order ( $\S 64)$ is possible under the following conditions:

a) if a person has an addiction to alcohol or other drugs;

б) if person is convicted of an unlawful act (crime or offence) committed while he was in such state or as a result of his addiction, or is not convicted only because he has been found to be insane and insanity is proven and not excluded;

c) if there is a danger that person will commit future serious unlawful acts as a consequence of his addiction.

A set of features, typical for general characteristics of such measures should be singled out:

1. With regard to the sequence of execution of measure (mental hospital orders, custodial addiction treatment orders) and punishment it is possible to notice that the former shall be served, as a rule, before the punishment if the court finds that the purpose of the measure will thereby be better facilitated ( $\S 67)$.

2. If a mental hospital order or a custodial addiction treatment order have been made, it is possible to replace the measure with the other of those measures if this would improve the chances of re-socialisation of this person ( $\$ 67 a$, subparagraph 1).

3. In most cases when mental hospital orders or a custodial addiction treatment orders are made the court orders to suspend these measures if "special circumstances justify the expectation that the purpose of the measure may be achieved in this manner". In such cases the person is subjected to supervision (§ 67b, sub-paragraphs 1, 2).

4. If a custodial sentence is served prior to measures ordered or at the same time, the court shall review, before the sentence has been served, whether the purpose of the measure still requires its enforcement, if it does not, the court shall order conventional suspension of such measure and the person is subjected to supervision (§ 67c, sub-paragraph 1).

Thus, German legislation provides the widest range of security measures (known as "correctional and security measures"), among which, for our opinion, the most severe is detention for the purpose of prevention ( $\$ 66$ of the CC of Germany), considering that it appears to be "deprivation of person's liberty as prevention of possible commission of criminally punishable act by him for a some period rather than sentencing him for a committed crime. Some countries (modern Germany) administrate it as one of security measures to the professional and "incorrigible" offenders, others as measure of political repression (Hitlerite Germany, Indonesia from 1996)" ( Bakhvalova L.A., 2012).

The danger from the person may be connected with his mental disorder resulting in possible causing of considerable harm by the person to himself or other persons, society or state, with sexual preference disorder of infants, with minority (art. 97, p.2; art. 90 of CC of the RF, the Law on the Administration of Juvenile Justice of 08.04.1953)

It is important to note that the system of criminal legal measures applied to minors in Russia includes punishment, compulsory educational measures and possibility of conditional sentencing. At the same time the list of penalties is cut down comparing to that envisaged for persons having attained the age of 18 as well as terms and amounts of certain types of penalties are reduced.

Pursuant to the Law on the Administration of Juvenile Justice in Germany the following system of sanctions for minors exists: educational measures (Erziehungsmassregeln), compulsory measures (Zuchtmittel) and penalty imposed for minors (Jugendstrafe). Contrary to Russian legislation in Germany the only type of punishment applicable to minors is deprivation of liberty. The measures similar to Russian's (e.g. apprehension, community services, payment of financial contribution) the German legislator includes into the group of educational measures and compulsory measures (The Big Legal Dictionary Academic.ru, 2010). In Switzerland, for example, difficult minors may be subjected along with educational aid to custodial placement up to 14 days (art. 91 of CC of Switzerland).

In the Russian Federation the minors shall be subjected to such compulsory measures of educational influence as transfer to the surveillance of parents or persons acting in loco parentis, or any specialized state agency, restriction of leisure and establishment of special requirements for the behaviour of a minor for a period of between 1 month and 2 years when convicted for a crime of limited gravity and between 6 month and 3 years when convicted for a crime of average gravity. The minor may be placed in a closed-type special education institution up to the age of 18 , but no more than for 3 years (art. 90, p. 3; art. 92, p. 2 of CC of RF).

The minimal term prescribed for compulsory medical measures is 6 month and the maximal depends on mental 
state of a person. The person subjected to the compulsory medical measure shall be examined by the psychiatric committee not less than once every six month, which decides whether to request the court to terminate or change the measure. Compulsory medical measures shall be prolonged, changed or terminated by a court upon a proposal submitted by the administration of the psychiatric establishment which carries out compulsory medical treatment, or the penal and correctional inspectorate, controlling the enforcement of compulsory medical measures, based on the findings of a psychiatric committee. The first extension of compulsory medical treatment may be made upon the expiry of six months after the beginning of treatment; subsequently, compulsory treatment shall be extended every year (art.102 of CC of the RF).

Security measures is a legal institution reflecting state policy with regard to economy of repression measures, on the one hand, and a mean of preventing commission of new socially dangerous actions by persons with mental health problems, on the other. Its efficiency depends on organization of measures implementation process, which implies preparation of qualified staff implementing such measures.

\section{References}

Bakhvalova L.A. (2012). Peculiarities of Legal Responsibility of Minors in Criminal Law of Russia and Germany. The Synopsis of Candidate's Thesis in Law.

Dodonov V.N. (2009). Comparative Criminal Law. General Part. "Yurlitinform".

Ganzglass, Martin R. (1971). The Penal code of the Somali Democratic Republic; with cases, commentary and examples. New Brunswick, N.J.

Golovanova N., Yeremin V., Ignatova M. et al. (2013). Criminal Law of Foreign Countries. General and Special Parts: Textbook for Master Students. Krylova N.Ye. (Ed.). 4th ed.

Golovanova N.A., Yeriomin V.N., Ignatova M.A. et al. (2010). Criminal Law of Foreign Countries. General and Special Parts: Textbook ; Kozochkin I.D. (Ed.). - 3rd ed. revised and enlarged.

Krylova N., Serebrennikova A. (2009). Criminal Law of Foreign Countries (England, USA, Germany).

Kuznuetsova N.V., Veltsel L. (1980). Criminal Law of Germany.

Laws on Preventive Detention Assignment Applied to Recidivists as Primary and Additional Sanction 2002-2004. (Gesetz zur Einführung der vorbehaltenen Sicherungsverwahrung of August 21, 2002 and Gesetz zur Einführung der nachträglichen Sicherungsverwahrung of July 23, 2004).

Paolo Contini (1964). Integration of Laws in the Somali Republic. Mogadiscio.

Reshetnikov F.M. (1975). Criminal Law of Foreign Countries. Is. 4. The Punishment.

Strafgesetzbuch (2014). Munich.

The Big Legal Dictionary Academic.ru (2010).

The Criminal Procedure Code of Democratic Republic of Somalia (1963). Mogadishu.

The Penal code of the Somali Democratic Republic (1962). Mogadishu.

Xeerka ka hortaga argagaxisada (2007). Muqdisho. 